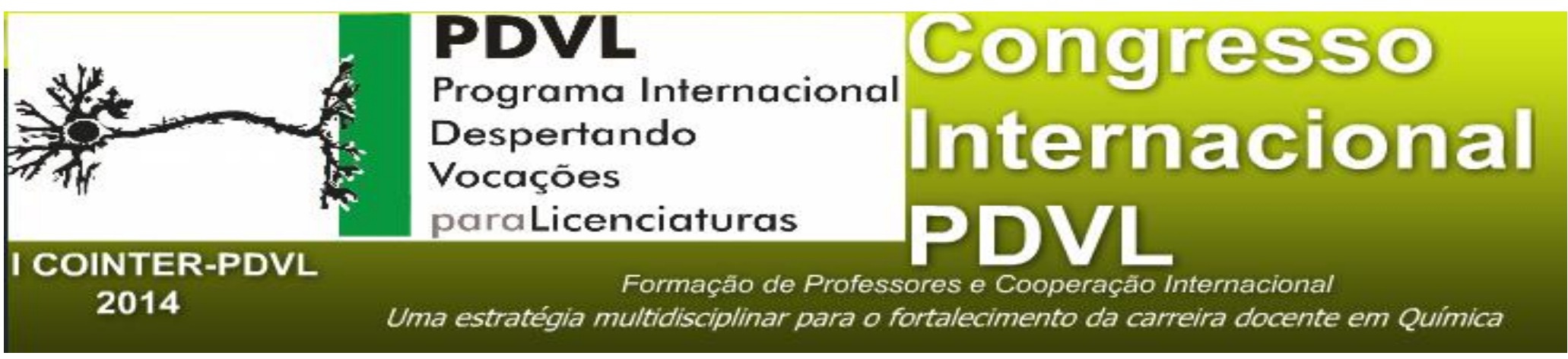

\title{
A CARREIRA DOCENTE EM QUÍMICA: PRÓS E CONTRAS EM RELAÇÃO À PROFISSÃO
}

Apresentação: Pôster

Wilson Xavier Barbosa ${ }^{1}$; Francisca Maria Silva Miranda ${ }^{2}$; Kilma da Silva Lima Viana ${ }^{3}$

\section{Introdução}

Os professores, especialmente, na área de Ciências Exatas e da Natureza, vêm, ao longo do tempo, reproduzindo práticas tradicionais que muitas vezes não ajudam no processo de construção do conhecimento (LIMA, 2008) e incentivo aos estudantes que desejam cursar uma Universidade.

As matrizes curriculares apresentadas nos projetos de cursos do Ensino Médio trazem uma organização que dificulta uma visão ampla dos conceitos (BASIL, 2001). As áreas de conhecimento, que deveriam dialogar, são dispostas de tal maneira que os estudantes não despertam interesse pela disciplina e muito menos pela profissão docente.

Diante disso, o objetivo dessa pesquisa foi identificar as concepções dos professores em relação à carreira docente e o Ensino de Química. Foi realizado um levantamento com três professores que lecionam a disciplina de Química em uma escola estadual do município de Vitória de Santo Antão. E, a partir dos nossos resultados, e análise dos mesmos, espera-se, com este trabalho, contribuir para a reflexão acerca do ensino e da carreira docente em Química.

\section{Fundamentação Teórica}

\footnotetext{
1 Licenciatura em Química/IFPE/Grupo de Estudos e Pesquisas em Ensino das Ciências/wilsonxavierbarbosa@gmail.com

2 Pedagoga/IFPE/Grupo de Estudos e Pesquisas em Ensino de Ciências/francisca.miranda @ vitoria.ifpe.edu.br

${ }^{3}$ Professora da Licenciatura em Química/IFPE/Grupo de Estudos e Pesquisas em Ensino de Ciências/kilma.viana@vitoria.ifpe.edu.br
} 
As leis nacionais da Educação traçaram caminhos para a formação do professor, nessa perspectiva Brasil (2001) afirma que "o licenciado em química deve ter formação generalista, mas sólida e abrangente em conteúdos dos diversos campos da Química, preparação adequada à aplicação pedagógica (...)". Muitos desses caminhos ainda não estão sendo visualizados e não estão sendo visto no ambiente da Educação Básica.

Maia (2005) afirma que os professores precisam tornar a aprendizagem dos estudantes significativa, promovendo interações entre os novos conhecimentos e os mesmos já existentes. É necessário que o professor assuma um papel de motivador de seus estudantes, despertando neles o desejo empírico, impulsionando-lhes a pensar e tornarem-se seres críticos e questionadores.

Nesse sentido, Auler (2007) enfatiza que os livros que falam do ensino de Química, contribuem para formação dos docentes nessa área, incentivando-os a criarem seu próprio programa de ensino e sua metodologia. Ressaltamos a importância de que os professores busquem em seus planejamentos novas maneiras de contribuir para a formação de seus estudantes, criando estratégias e os auxiliando a construção de significados reais para a vida cotidiana.

\section{Metodologia}

Essa pesquisa teve uma abordagem qualitativa e a coleta de dados se deu a partir de entrevistas semiestruturadas com os professores, que ministram a disciplina de Química, que apresentou as seguintes questões. As entrevistas tinham como base seis questões, a saber:

1. Você considera a disciplina Química de difícil compreensão?

2. Você reconhece dificuldade de compreensão dos conceitos químicos em seus estudantes?

3. Se reconhece, quais as principais dificuldades? A que você credita essa dificuldade?

4. Você visualiza estudantes seus, dessa turma, que poderiam seguir a carreira docente em Química?

5. Qual a sua percepção sobre a carreira docente em Química?

6. Você incentiva sues estudantes a seguirem a carreira docente em Química? Por quê?

A título de informação, os professores da pesquisa serão identificados neste trabalho como P1, P2 e P3. Após as respostas dos professores, foi possível analisarmos os resultados baseados nossos referenciais.

\section{Resultados e Discussões}

Em relação à primeira questão, quando perguntamos aos professores se consideravam a Química uma disciplina de difícil compreensão, os professores afirmaram que a mesma não é de 
difícil compreensão, porém necessita de conhecimentos prévios para melhor entendimento de conteúdos subsequentes.

Em relação às dificuldades de aprendizagem da Química, pelos estudantes, todos os professores veem essa deficiência, principalmente nos conteúdos que necessitam de um raciocínio matemático. Em relação a que o professor credita essas dificuldades, na visão do professor P1 se dá porque os "temas diversos da disciplina, tornam obrigatórios conhecimentos prévios". Na visão do professor P2, "as dificuldades de aprendizado da Química não são muito diferentes das que as demais ciências enfrentam", já no olhar do professor P3, a "ausência da prática no cotidiano" e'um dos motivos apresentados.

Dando continuidade, realizamos mais três indagações. Perguntamos se o professor visualizava estudantes da turma que poderiam seguir a carreira docente em Química? Os professores P1 e P3 afirmaram que "sim". O professor P3 complementou, afirmando que "alguns alunos têm uma maior dedicação no que se refere aos estudos de Química e, com isso, possuem um excelente desempenho". Por outro lado, o professor P2 afirmou que a carreira docente não faz parte dos anseios dos estudantes atuais.

Perguntados qual era a percepção deles sobre a carreira docente em Química? O Professor P1 e P3 afirmaram que é uma carreira muito promissora e que está em crescente expansão. Por outro lado, o professor P2 disse que essa carreira é a quarta ou quinta opção dos estudantes que pretendem cursar uma Universidade.

Diante dessas repostas, perguntamos aos professores se eles incentivavam seus estudantes a seguirem a carreira docente em Química? E por quê? Segundo os professores P1 e P3 afirmaram que incentivam, entretanto, o professor P2 disse que não incentiva, mas também não desestimulam. Com relação aos porquês, os motivos já haviam sido citados nas questões anteriores.

\section{Conclusões}

Diante do exposto, fica evidente dois posicionamentos em relação à carreira docente em Química: alguns professores têm a visão de que a carreira docente é muito promissora e em crescente expansão, enquanto para outros não é tão promissora assim, pelo fato de apresentar aspectos que desestimular os profissionais da área.

O fato da falta de valorização do magistério aparece em diversas pesquisas na área. O fato a ressaltar é que o próprio profissional da área não estimula o estudante. A área de Química vem formando cada vez menos profissionais. Um número expressivo de professores que ministram aulas em Química no Ensino Médio não são formados na área. Esse quadro tende a piorar se estratégias 
não foram criadas para a superação dessa realidade e enquanto os próprios professores não fazerem parte dessa luta.

Como vimos, muitos professores relacionam a disciplina de Química uma disciplina que necessita de conhecimentos matemáticos para a sua compreensão, dificultando a apropriação dessa área. É preciso que as aulas de Química superem a matematização e resgate a sua natureza para que a cada dia possam ser conquistados mais e mais estudantes.

\section{Referências}

AULER, D. Enfoque ciência-tecnologia-sociedade: pressupostos para o contexto brasileiro. Ciência \& ensino: v.1, número especial, nov 2007. 20p.

Brasil. Orientações curriculares para o ensino médio - ciências da natureza, matemática e suas tecnologias. Brasília: ministério da educação, secretaria de educação básica, 2006.

LIMA, K. S. Compreendendo as concepções de avaliação de professores de física através da teoria dos construtos pessoais. Recife, 2008. 163 p. Dissertação (Mestrado em Ensino das Ciências). PróReitoria de Pesquisa e Pós-Graduação, Universidade Federal Rural de Pernambuco, 2008.

MAIA. P. Instituto nacional de ciência e tecnologia de transferência de materiais. Fortaleza, Ceará- Brasil.2005 